\title{
Two novel mutations confirm FGD1 is responsible for the Aarskog syndrome
}

\author{
CE Schwartz ${ }^{1}$, G Gillessen-Kaesbach ${ }^{2}$, M May $^{1}$, M Cappa $^{3}$, J Gorski ${ }^{4}, \mathrm{~K}_{\text {Steindl }}{ }^{5}$ and \\ G Neri ${ }^{5}$
}

\begin{abstract}
${ }^{1}$ Center for Molecular Studies, JC Self Research Institute Greenwood Genetic Center, Greenwood, SC, USA; ${ }^{2}$ Institut für Humangenetik, Universität Essen, Essen, Germany; ${ }^{3}$ Ospedale Bambino Gesu, IRCCS, Roma, Italy; ${ }^{4}$ Department of Human Genetics and Department of Pediatrics, University of Michigan, Ann Arbor, MI, USA; ${ }^{5}$ Istituto de Genetica Medica, Policlinico Universitario A Gemelli, Università Cattolica, Roma and Centro Ricerche sulla Disabilità Mentale e Motoria, Associazione Anni Verdi, Roma, Italy
\end{abstract}

The Aarskog syndrome or facio-genital dysplasia (FGDY, MIM No. 305400) is an X-linked condition characterized by short stature, macrocephaly, facial, genital and skeletal anomalies. It is caused by mutation of the FGD1 gene mapped to the Xp11.21 region. To date, only one point mutation has been reported in an affected family, consisting of the insertion of an additional guanine residue at nucleotide 2122 of exon 7, which causes premature translational termination. We now report the finding of two novel FGD 1 mutations, a missense mutation in a family of Italian origin and a deletion of 3 exons in a sporadic case from Germany. These mutations confirm the role of FGD1 as the gene responsible for the Aarskog syndrome. European Journal of Human Genetics (2000) 8, 869-874.

Keywords: Aarskog syndrome; FGD1; mutation; FGDY

\section{Introduction}

Aarskog syndrome (FGDY) is a multiple congenital anomalies/dysplasias syndrome. ${ }^{1,2}$ Minor anomalies and/or malformations usual ly affect the midline and the urogenital system (hypertelorism, umbilical hernia, shawl scrotum, hypospadias, undescended testes), while dysplastic changes involve the skeleton, resulting in vertebral and phalangeal defects and shortness of stature. The syndrome was first described at the Third Conference (1970) on the Clinical Delineation of Birth Defects by Aarskog ${ }^{3}$ and Scott $^{4}$ in two different families with multiple affected males. Aarskog suggested the condition was $\mathrm{X}$-linked, noting that female carriers might exhibit mild short stature. The FGDY gene had been mapped to the pericentromeric region of the $X$ chromosome by the observation of an $\mathrm{X} ; 8$ translocation in an affected mother and son. ${ }^{5}$ Porteus et $\mathrm{al}^{6}$ and Stevenson et $\mathrm{al}^{7}$ linked the Aarskog gene to Xp11.3-Xq13. Glover et al ${ }^{8}$ precisely assigned the breakpoint to Xp11.21 on re-evaluation of the chromosomes in 1993.

Correspondence: Charles Schwartz, Center for Molecular Studies, JC Self Research Institute, 1 Gregor Mendel Circle, Greenwood, SC 29646, USA. Tel: + 18649418140 ; Fax: + 18643881707 ;

E-mail: schwartz@ggc.org

Received 25 April 2000; revised 15 June 2000; accepted 12 July 2000
This localization allowed the cloning of FGD1, the gene responsible for the syndrome. ${ }^{9}$ FGD1, which encodes a 961 amino acid zinc finger protein with strong homology to the Rho/Rac guanine nucleotide exchange factors (GEF), was shown to be interrupted by the $t(X ; 8)$ breakpoint. Until now, only one point mutation had been reported in an affected family, consisting of an insertion of an additional guanine residue at nucleotide 2122 of exon 7 , which causes premature translational termination. ${ }^{9}$

\footnotetext{
Methods

Patients

In family K8345, two maternally related male cousins, FC and IT (see III-1, III-3, respectively, Figure $3 \mathrm{~A}$ ), were referred because of short stature and peculiar face at the age of 7 and $18 / 12$ years, respectively. The mothers, who are sisters, are also short, whilst a brother of theirs appears to be phenotypically normal. FC is the only child, and the mother's second pregnancy ended in early spontaneous abortion. IT has an older brother who is normal. The second pregnancy of the mother ended in the late spontaneous abortion of a pair of twins, one male and one female. The third pregnancy ended at 8 months with the stillbirth of a male fetus. The propositi,
} 
in addition to being short, had relative macrocephaly and a strikingly similar face with ocular hypertelorism, downslanting palpebral fissures, ptosis of the upper eyelids, flat philtrum, bow shape of the upper lip and pointed chin (Figure1). They also had brachydactyly, typical hyperextensibility of the proximal and incomplete extensibility of the distal interphalangeal joints, and transverse palmar crease. Also noted were umbilical (FC) and inguinal (IT) hernia, dorsal groove of the penis (FC) and shawl scrotum (IT). Psychomotor development was normal in both.

Patient MK (CM S0843) was referred for genetic evaluation at age 3 years because of short stature. His height was $91 \mathrm{~cm}$ $(-2.6 \mathrm{SD})$ and his head circumference was $47 \mathrm{~cm}$ (-2.8SD). He had a widow's peak, hypertelorism, downslanting palpebral fissures, ptosis of the upper eyelids and a short nose with anteverted nares (Figure2A). Also present were brachydactyly and cutaneous syndactyly of both hands (Figure2B), and a shawl scrotum. At age 5 years 11 months bone age was retarded and dissociated, corresponding to 2 to 4 years. By age 9 he had developed myopia and at age 11 he was operated on because of an inguinal hernia and cryptorchidism. The patient has had normal psychomotor development. There was no family history of Aarskog syndrome.

\section{SSCP analysis}

Exons 2, 3, 5-17 and the promoter region were amplified as individual units except for exons 7 and 8 which were amplified as one amplicon of $428 \mathrm{bp}$. Primers (Table1) were designed based on the FGDY intron/exon sequences deposited in GenBank (Accession Nos. U11690, L48693-L48709).
All primers were synthesized and labeled with fluorescein amidite (FluorePrime, Amersham Pharmacia Biotech, Piscataway, NJ, USA) on a Beckman Oligo 1000 DNA synthesizer and desalted through sephadex G-25 (NAP-10 columns, Amersham Pharmacia Biotech, Piscataway, NJ, USA). After amplification, $1 \mu \mathrm{l}$ of a 1:5 dilution of the PCR product was added to a $0.3 \mu \mathrm{l}$ each of two sizers flanking the amplicon and $2 \mu \mathrm{l}$ of loading dye ( $100 \%$ dionized formamide, $5 \mathrm{mg} / \mathrm{ml}$ Dextran Blue 2000). SSCP analysis was conducted using an Automated Laser Fluorescent Sequencer (Amersham Pharmacia Biotech, Piscataway, NJ, USA) under the following conditions: $1500 \mathrm{~V}, 43 \mathrm{~mA}, 25 \mathrm{~W}$ at $20^{\circ} \mathrm{C}$ with a sampling interval of $1.25 \mathrm{~s}$. The gel matrix was $0.5 \mathrm{X}$ MDE (FMC).

\section{Restriction endonuclease fingerprinting (REF)}

As the PCR products for exons1, 4, and 18 are $10396 \mathrm{bp}$, $588 \mathrm{bp}$, and $956 \mathrm{bp}$, respectively, these were analyzed using REF. ${ }^{10,11}$ After amplification, $8 \mu$ of the PCR product was digested with $4 U$ of each enzyme in separate reactions. For exon 1, Vmal, Hinfl and BamHI + Sacll were used to generate fragments. For exon 4, Acil, Mspl, Alul, Banl + Hinfl and Banl + Hincll were used. For exon 18, Dral + NlallI, Dral+ Banll and Alul + Banl were used. All digestions contained $0.4 \mathrm{U}$ of calf intestinal alkaline phosphatase, (Roche Molecular Biochemicals, Indianapolis, IN, USA). After overnight digestion, these tubes were heated to $96^{\circ} \mathrm{C}$ for $10 \mathrm{~min}$ and $5 \mu \mathrm{l}$ of each digestion were mixed together and heated a second time at $96^{\circ} \mathrm{C}$ for $10 \mathrm{~min}$ to insure inactivation of the
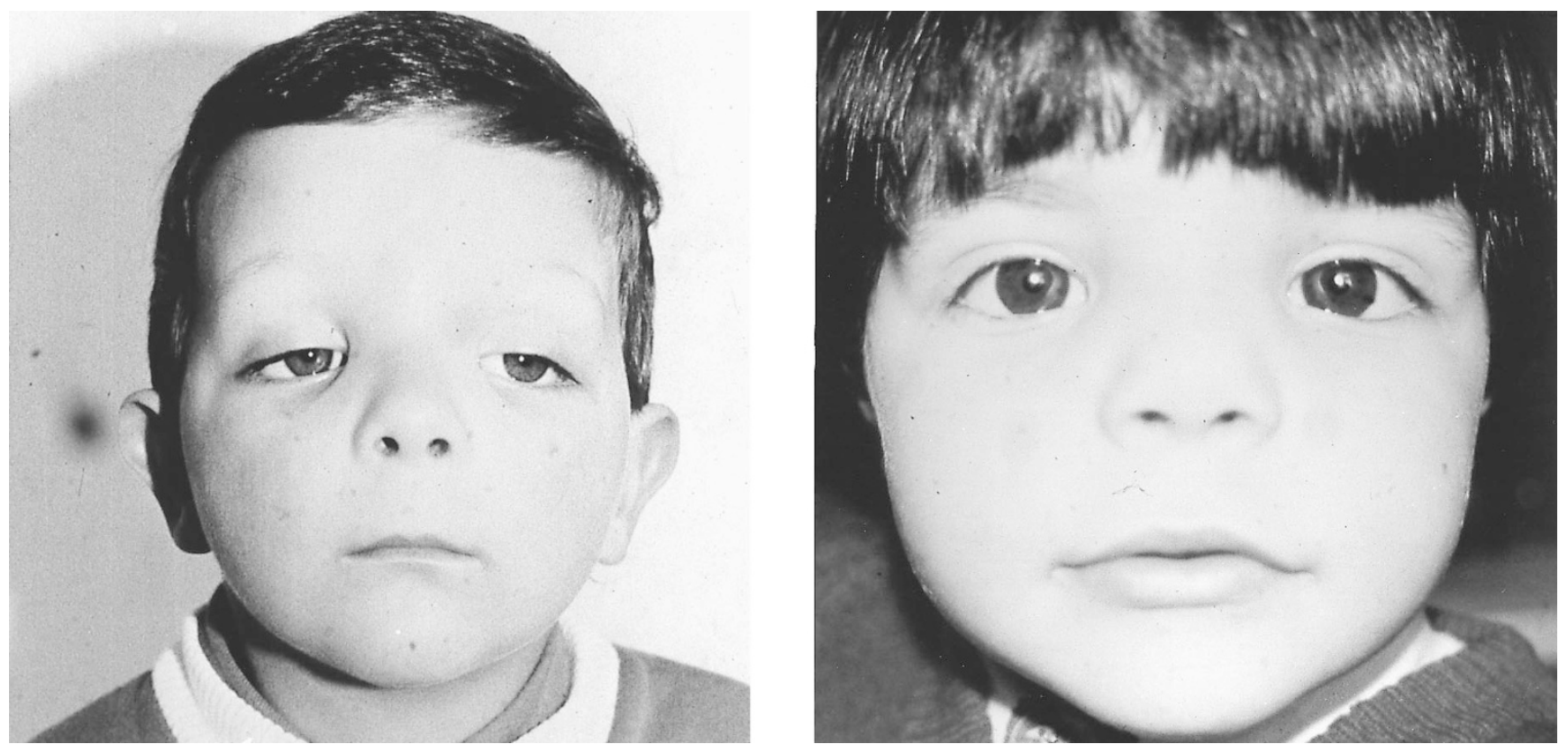

Figure 1 Facial appearance of the two probands in K8345 with Aarskog syndrome, left, person III-1, right, person III-3. 
A

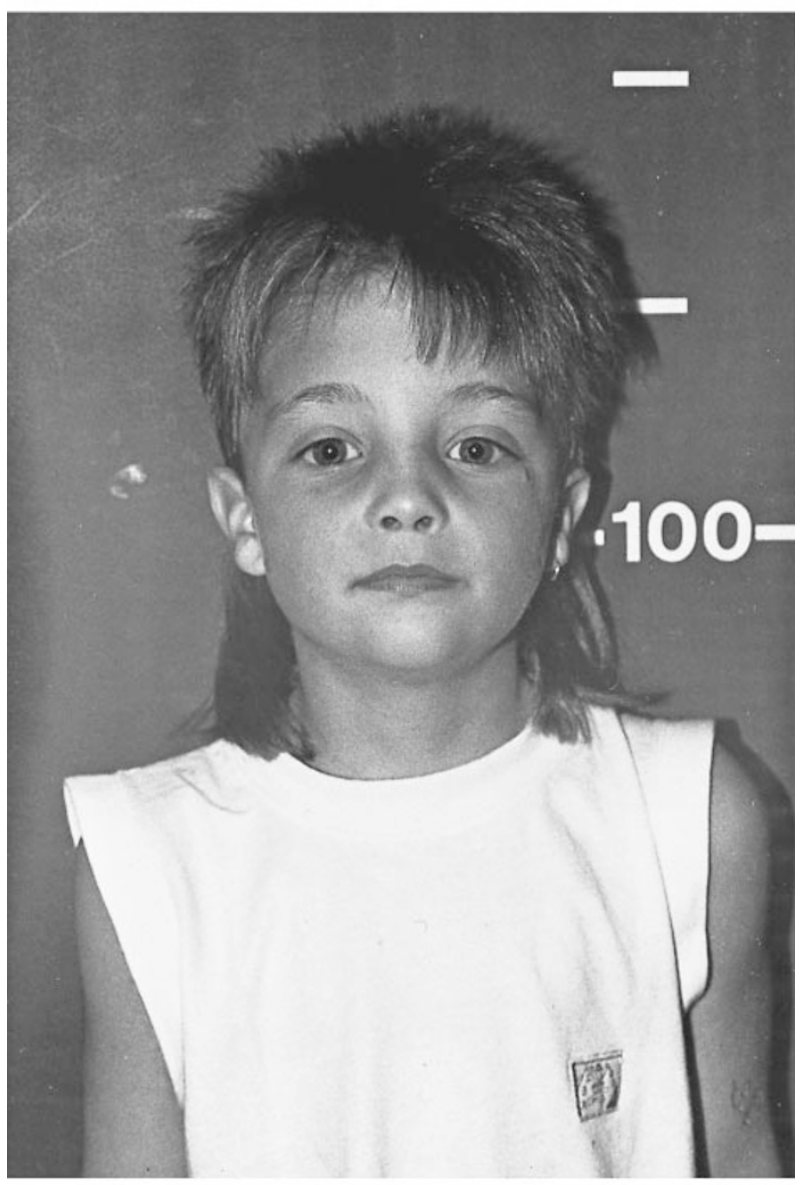

B

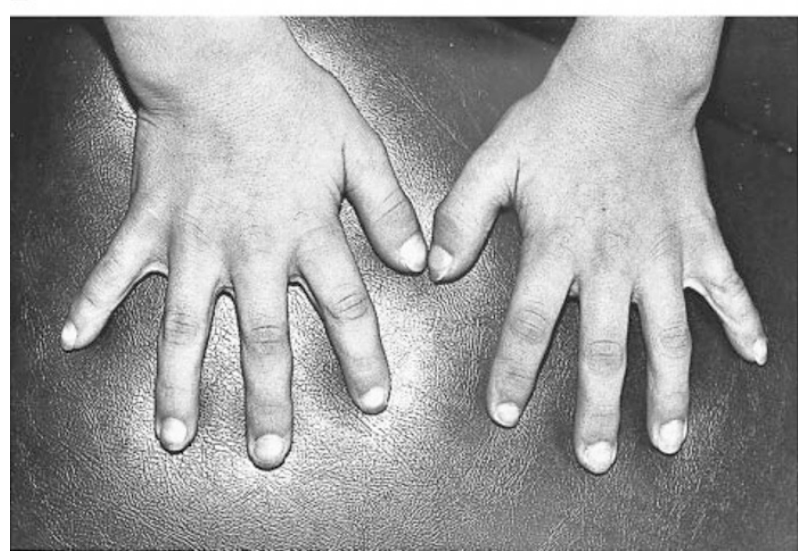

Figure 2 A Facial appearance and B hands of patient MK.

phosphatase. Approximately $11 \mathrm{ng}(1.1 \mu \mathrm{l})$ of the digested fragments were $5^{\prime}$ end-labeled and electrophoresis was performed as described previously. ${ }^{11}$

\section{Sequencing}

The exon 7-8 PCR product was sequenced on the ALF using fluorescein labeled primers and a cycle sequencing kit (Promega, Madison, WI, USA). The gel conditions were as follows: $6 \%$ polyacrylamide at $45^{\circ} \mathrm{C}, 1.25 \mathrm{~s}$ sampling time. The gel was run for $10 \mathrm{~h}$.

\section{Results}

We screened the 18 exons and the promoter region of the FGD1 gene which were analyzed either by SSCP (promoter, exons 2, 3, 5-17) or restriction endonuclease fingerprinting (exons $1,4,18$ ). An altered SSCP pattern was observed for the PCR product containing both exons 7 and 8 in patient III-1 of family K8345 (data not shown). Sequence analysis showed a $\mathrm{G}$ to $\mathrm{A}$ alteration (G2296A) causing an arginine to be replaced with an histidine (R522H) (Figure 3B). The $G$ to A change eliminates an Acil site in the normal sequence. The lack of the Acil site segregated with the Aarskog syndrome in the family (Figure $3 \mathrm{~A}$ ) and its absence was not detected in 100 normal $X$ chromosomes in the Italian population. Thus, it is highly unlikely that the alteration is a normal polymorphism.

Exon analysis of patient CMS0843 demonstrated a lack of amplification of exons9-12 (Figure4). The exact extent of the deletion has yet to be determined.

\section{Discussion}

We now report the finding of two mutations of FGD1 that cause Aarskog syndrome. FGD 1 was first described by Pasteris et al. ${ }^{9}$ The authors proposed the gene was involved in the Aarskog syndrome based on two observations. First, it was directly disrupted by a $t(X ; 8)$ breakpoint present in a mother and her affected son. ${ }^{5,8,9}$ Second, analysis of a small family with two affected male siblings revealed an insertion of an additional guanine residue at position 2122 in exon $7 .{ }^{9}$ This frameshift was likely to result in a premature stop codon to appear at residue469. However, since the original report of Pasteris et $\mathrm{al}^{9}{ }^{9}$ no other mutations in FGD 1 have been reported. We have identified two additional mutations in FGD1. An Italian family with FGDY was found to have an $\mathrm{R} 522 \mathrm{H}$ mutation in the third SCR (structural conserved region) of GEF domain of FGD 1. The arginine at codon 522 is highly conserved, being present in three other Rho/Rac GEF proteins. Two other members of the Rho/Rac GEF family have a lysine in place of the arginine. ${ }^{9}$ The bulkier histidine with its ring side chain probably alters the conformation of the GEF domain, thereby adversely affecting the protein's ability to efficiently activate Rho/Rac proteins by exchanging bound GDP for free GTP. ${ }^{12}$ We consider this sufficient evidence to support the conclusion that the observed mutation is responsible for the Aarskog syndrome in the present family. This conclusion is further supported by the absence of this mutation in 100Italian control $X$ chromosomes. 
Table 1 Primers and annealing temperatures for amplification of exons from the human FGD1 gene

\begin{tabular}{|c|c|c|c|c|}
\hline Exon & Primer $\mathrm{F}$ & Primer $\mathrm{R}$ & $\begin{array}{l}\text { Annealing temp } \\
\text { (deg C) }\end{array}$ & $\begin{array}{l}\text { Product size } \\
\text { (Bp) }\end{array}$ \\
\hline Promoter & 5' agccaagccctaggaacactgag 3' & 5' gcagccgcagccacagc 3' & 55 & 309 \\
\hline 1 & 5' agagcggtagcagcgagaagtgag 3' & 5' ccccaaaggccgaggtaagc 3' & 55 & 1250 \\
\hline 2 & 5' acacccattttctcccttcc 3' & 5' gtggctccctatccttctaaca 3' & 55 & 325 \\
\hline 3 & 5' agtgcccccaaagcccagctac $3^{\prime}$ & 5' ccaggctccccctttccctagag 3' & 55 & 228 \\
\hline 4 & $5^{\prime}$ ggaagggatagtcaggag $3^{\prime}$ & $5^{\prime}$ gaagaatcaagcacaaag 3' & 55 & 588 \\
\hline 5 & 5' gggcttgggtgagggttacgat $3^{\prime}$ & 5' ggccctatcactgcctccttgaaa $3^{\prime}$ & 55 & 223 \\
\hline 6 & $5^{\prime}$ ctgccctgccegacaggtgtt $3^{\prime}$ & 5' tcggcaggcaggtggacagg 3' & 55 & 197 \\
\hline $7 \& 8$ & $5^{\prime}$ ccacccagggaccgctat $3^{\prime}$ & 5' acactcatttgggcatccttgct $3^{\prime}$ & 50 & 418 \\
\hline 9 & 5' tctctgctagtcccccatctga 3' & $5^{\prime}$ cctcctcgcccectaaca $3^{\prime}$ & 60 & 295 \\
\hline 10 & 5' cgtgccttttgttccctgtctttt $3^{\prime}$ & 5' gggcatgacccacccacaat $3^{\prime}$ & 57 & 258 \\
\hline 11 & 5' acatccccactaggccctctgc 3' & 5' ttcctcccaacaccaatgc 3' & 58 & 205 \\
\hline 12 & 5' cctcaccatgccectttctgc 3' & 5' tctgggcctggaatgcctcag 3' & 60 & 190 \\
\hline 13 & 5' gggcctacctaaccaaacatctt $3^{\prime}$ & 5' caccctcaccttatacaccctcag 3' & 55 & 321 \\
\hline 14 & 5' acgaaggtgaggcaggggtaga 3' & 5' ggtcaggtgggcatttggaagt $3^{\prime}$ & 58 & 238 \\
\hline 15 & 5' cccctacccccagcccaatc 3' & 5' tcttcccttcagcataccaactcc 3' & 60 & 194 \\
\hline 16 & 5' aagtctgctgtgggagttgg 3' & $5^{\prime}$ tgtgggagagttcgtcagg $3^{\prime}$ & 55 & 275 \\
\hline 18 & 5' aggtggccccagctctgtcc 3' & $5^{\prime}$ ccccctgtttccctgtcctg 3' & 60 & 903 \\
\hline
\end{tabular}

A $\mathrm{K} 8345$

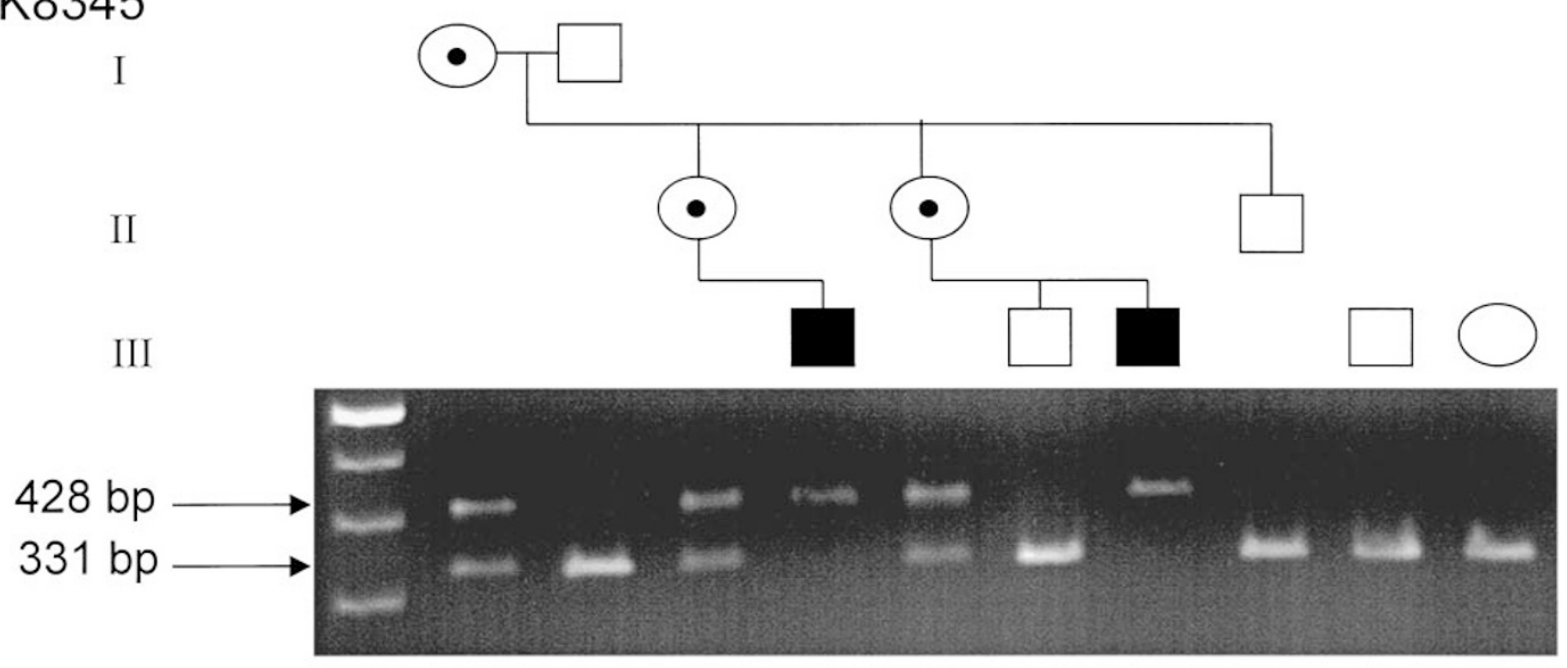

B

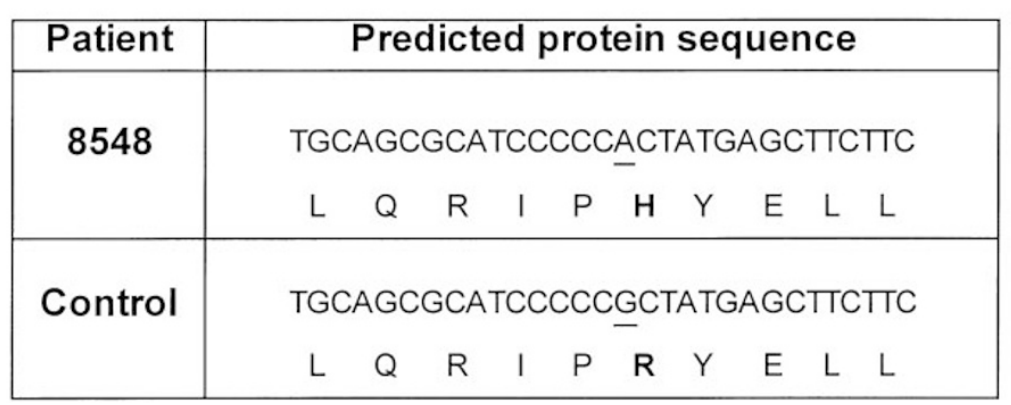

Figure 3 A Pedigree of family K8345. PCR product of exon 8 was digested with Aci I. The presence of a band of 331 bp represents normal X chromosome. The 428 bp band represents an X chromosome with the G2296A mutation B DNA sequence and predicted amino acid sequence for the normal and abnormal FGD1 exon 8 . The base alteration is indicated by underlining and the resulting amino acid change $(\mathrm{R} 522 \mathrm{H})$ is indicated in bold. 


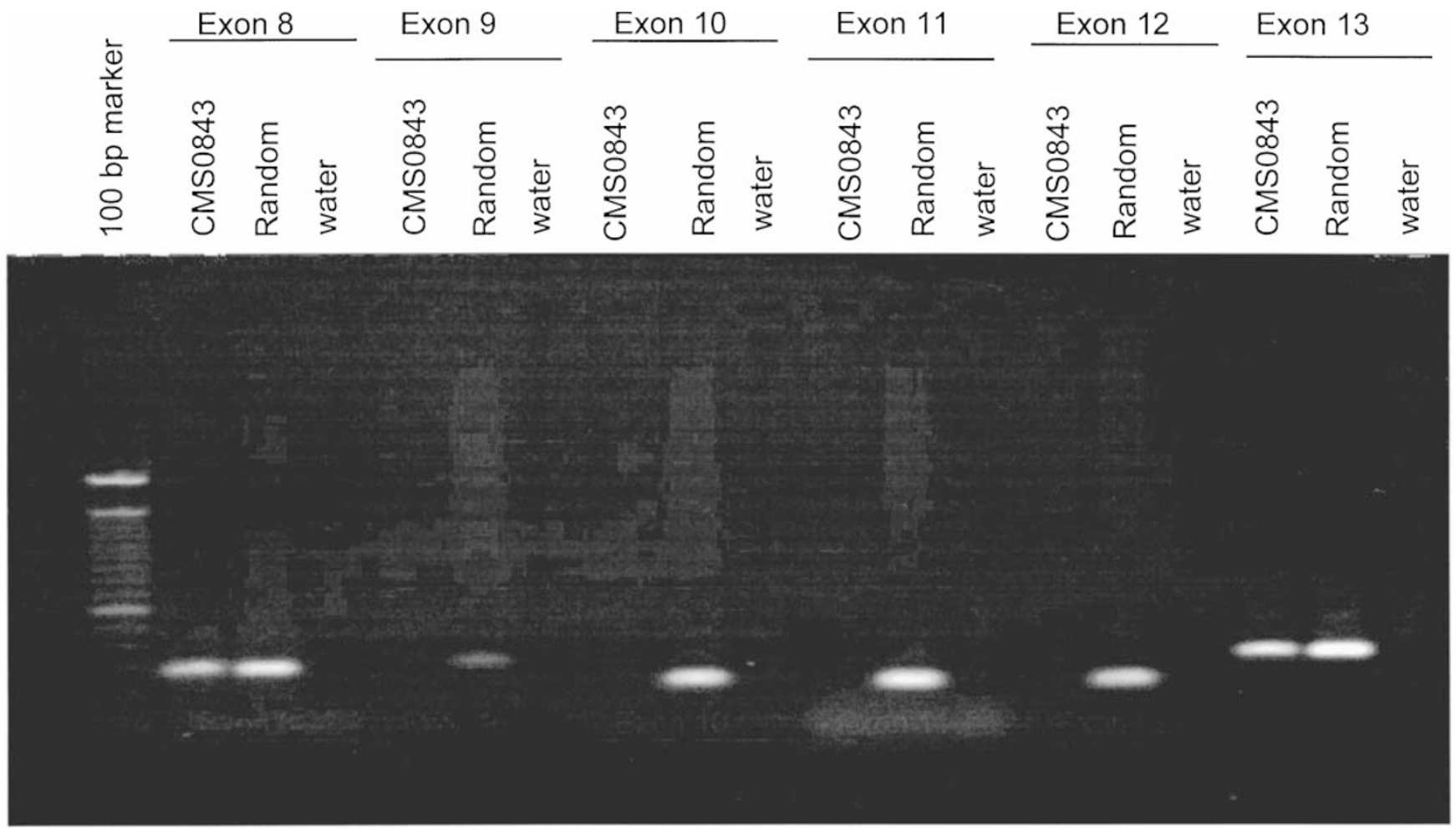

Figure 4 Exon 8-13 analysis of patient CMS0843. Primres for exons8-13 were designed as described in Methods. Random lane is a normal male control. $\mathrm{H}_{20}=$ blank control containing all reaction reagents without genomic DNA. PCR products were run on a $2 \%$ agarose gel and visualized using Ethidium bromide.

The second mutation was found in a sporadic patient with clinical features consistent with a diagnosis of FGDY. He was found to have a genomic deletion involving exons 9 to 12 in the FGD1 gene. Whilst the effect of the deletion at the transcript level has yet to be determined, at a minimum, the altered gene would lack the last 13 amino acids of the GEF domain (aa546-559), a portion of a PH1 domain (aa590-635) and a leucine zipper domain (aa636-659) if the deletion was in-frame. The absence of these critical segments would certainly adversely affect the function of FGD 1 .

Since the phenotype associated with the syndrome is quite consistent across many families and ethnic backgrounds, we had expected to find a common mutation. However, this has not been the case. The three mutations thus far reported, including the present ones, are unique to an individual family. Furthermore, we have been unable to detect similar alterations in FGD 1 in propositi from 25 families and 15 sporadic case. These include families utilized to establish linkage to $\mathrm{Xp} 11.4^{7}$ as well as the families originally reported by Aarskog $^{3}$ and Scott. ${ }^{4}$

This raises the possibility that some mechanism other than a point mutation or small deletion is responsible for the FGDY phenotype. Such an occurrence has not been uncommon in recent years. Friedreich ataxia is due to a GAA repeat expansion in intron 1 in the $\times 25$ gene; ${ }^{13}$ over $60 \%$ of Pelizaeus-Merzbacher disease (PMD) results from duplica- tions of the PLP gene; ${ }^{14,15}$ and $42 \%$ of severe hemophilia A results from an inversion involving intron 22 of Factor XIII. ${ }^{16,17}$ All these mutations were not detected using standard mutational analyses of coding sequence genomic DNA. We are currently investigating whether any of these mechanisms are involved in producing the FGDY phenotype.

\section{Acknowledgements}

This research was supported in part by a grant from the South Carolina Department of Disabilities and Special Needs (SCDDSN) and a NICHD grant (HD26202) to CES.

\section{References}

1 Porteous MEM, Goudie DR: Aarskog syndrome. J Med Genet 1991; 28: 44-47.

2 Gorlin RJ, Cohen MM, Levin LS: Syndromes of the Head and Neck, 3rd edn. Oxford University Press: New York, 1990, pp 295-297.

3 Aarskog D: A familial syndrome of short stature associated with facial dysplasia and genital anomalies. J Pediatr 1970; 77: 856-861.

4 Scott CJ Jr: Unusual facies, joint hypermobility, genital anomaly and short stature: A new dysmorphic syndrome. National Foundation-March of Dimes. Alan R Liss: New York, 1971, pp 240-246.

5 Bawle E, Tyrkus M, Lipman S, Buzimowski D: Aarskog syndrome: Full male and female expression associated with an X-autosome translocation. Am J Med Genet 1984; 17: 595-602. 
6 Porteous MEM et al: The gene for Aarskog syndrome is located between DXS255 and DXS566 (Xp11.2-Xq13). Genomics 1992; 14: 298-301.

7 Stevenson RE et al: Aarskog-Scott syndrome: Confirmation of linkage to the pericentric region of the X chromosome. Am J Med Genet 1994; 52: 339-345.

8 Glover TW et al: Translocation breakpoint in Aarskog syndrome maps to Xp11.21 between Alas2 and DXS323. Hum Mol Genet 1993; 10: 1717-1718.

9 Pasteris NG et al: Isolation and characterization of the faciogenital dysplasia (Aarskog-Scott syndrome) gene: A putative Rho/Rac guanine nucleotide exchange factor. Cell 1994; 79: 669-678.

10 Liu Q, Sommer SS: Restriction endonuclease fingerprinting (REF): A sensitive method for screening mutations in long, contiguous segments of DNA. Bio Tech 1995; 18: 470-477.

11 Du Y-Z, Srivastava AK, Schwartz CE: Multiple exon screening using restriction endonuclease fingerprinting (REF). Detection of six novel mutations in the L1 Cell Adhesion Molecule (L1CAM) gene. Am J Hum Genet 1996; 59(suppl): 1480.
12 Boguski MS, McCormick F: Proteins regulating Ras and its relatives. Nature 1993; 366: 643-653.

13 Campuzano V, Montermini L, Molto MD et al: Friedreich's ataxia: autosomal recessive disease caused by an intronic GAA triplet repeat expansion. Science 1996; 271: 1423-1427.

14 Sistermans EA, de Coo RF, De Wijs IJ, Van Oost BA: Duplication of the proteolipid protein gene is the major cause of PelizaeusMerzbacher disease. Neurology 1998; 50(6): 1749-1754.

15 Mimault C, Giraud G, Courtois V et al: Proteolipoprotein gene analysis in 82 patients with sporadic Pelizaeus-Merzbacher Disease: Duplications, the major cause of the disease, originate more frequently in male germ cells, but point mutations do not. Am J Hum Genet 1999; 65: 360-369.

16 Lakich D, Kazazian HH Jr, Antonarakis SE, Gitschier J: Inversions disrupting the factor VIII gene are a common cause of severe haemophilia A. Nat Genet 1993; 5: 236-241.

17 Naylor J, Brinke A, Hassock S, Green P, Giannelli F: Characteristic mRNA abnormality found in half the patients with severe haemophilia A is due to large DNA inversions. Hum Molec Genet 1993; 2: 1773-1778. 